\title{
CONTENTS OF VOLUME 20, I99I
}

ARTICLES

M. AGAR: The biculture in bilingual

167

J. Blommaert \& J. Verschueren: The pragmatics of minority politics in Belgium

E. D. Cook: Linguistic divergence in Fort Chipewyan

503

423

R. M. W. Dixon: A changing language situation: The decline of Dyirbal, $1963^{-1989}$

L. Glinert \& Y. Shilhav: Holy land, holy language: A study of an Ultraorthodox Jewish ideology

J. Halverson: Olson on literacy

P. M. Harvey: Drunken speech and the construction of meaning: Bilingual competence in the Southern Peruvian Andes

J. Jepson: Urban and rural sign language in India

B. Johnstone: Individual style in an American public-opinion survey:

Personal performance and the ideology of referentiality

G. LANOuE: Language loss, language gain: Cultural camouflage and social $\begin{array}{ll}\text { change among the Sekani of Northern British Columbia } & 87\end{array}$

G. H. Lerner: On the syntax of sentences-in-progress

C. LuCAS \& C. VALli: ASL or contact signing: Issues of judgment $20 \mathrm{I}$

M. Minami \& A. MCCABE: Haiku as a discourse regulation device: A stanza analysis of Japanese children's personal narratives

M. B. H. Rampton: Interracial Panjabi in a British adolescent peer group $39 \mathrm{I}$

Z. RÉger \& J. B. Gleason: Romāni child-directed speech and children's language among Gypsies in Hungary

L. O. Salami: Diffusion and focusing: Phonological variation and social networks in Ile-Ife, Nigeria

K. A. Watson-Gegeo \& D. W. Gegeo: The impact of church affiliation on language use in Kwara'ae (Solomon Islands)

A. WIERZBICKA: Japanese key words and core cultural values

Y. YoNGLIN: How to talk to the supernatural in Shakespeare

JU ZHUCHENG: The "depreciation" and "appreciation" of some address terms in China

REVIEWS

R. Astås: Et bibelverk fra middelalteren: Studier i Stjórn, Bind I \& 2 (Cathey)

J. BAldwin \& P. French: Forensic linguistics (Shuy)

K. H. BAsso: Western Apache language and culture: Essays in linguistic anthropology (Kroskrity)

D. BIBER: Variation across speech and writing (Algeo)
306

64 I

309

650 
S. Blum-Kulka, J. House, \& G. Kasper (eds.): Cross-cultural pragmatics: Requests and apologies (Holmes)

T. Bull, E. H. JAHR, \& G. WÏGGEN (eds.): Mål og medvit: Heidersskrift til Kjell Venås på 60-årsdagen 30 November 1987 (Haugen)

G. Calbris: The semiotics of French gestures (Lindenfeld)

J. Cheshire, V. Edwards, J. Münstermann, \& B. Weltens (eds.): Dialect and education: Some European perspectives (Auer) 282

K. CMIEL: Democratic eloquence (Thomas)

N. Coupland (ed.): English in Wales (James)

R. DARNELL: Edward Sapir: Linguist, anthropologist, humanist (Murray)

A. J. DevitT: Standardizing written English: Diffusion in the case of Scotland, 1520-1659 (Joseph)

G. Drigeard, P. Fiala, \& M. Tournier (eds.): Courants sociolinguistiques (Lindenfeld)

M. L. EDWARDS: Introduction to applied phonetics: Laboratory workbook (D. Hymes)

N. FAIRClOUGH: Language and power (Huspek)

N. FAIrclough: Language and power (Zupnik)

S. Gass, C. Madden, D. Preston, \& L. Selinker (eds.): Variation in second language acquisition. Vol. I: Discourse and pragmatics. Vol. 2: Psycholinguistic issues (Scarcella)

R. HARrIson: Signs, songs, and memory in the Andes: Translating Quechua language and culture (Hornberger)

J. Holm: Pidgins and creoles. Vols. I \& 2 (McWhorter)

K. JANICKI (ed.): Sociolinguistics in Poland (D. Jutronić-Tihomirović)

K. JANICKI: Toward non-essentialist sociolinguistics (Parmentier)

B. H. JERnUdD \& M. J. ShapIRo (eds.): The politics of language purism (Kahane)

J. KELLY \& J. LOCAL: Doing phonology: Observing, recording, interpreting (D. Hymes)

A. Kendon: Sign languages of Aboriginal Australia: Cultural, semiotic, and communicative perspectives (Rumsey)

C. Kerbrat-ORECCHIONI: Les interactions verbales (Lindenfeld)

M. Kontra (ed.): Beszélt Nyelvi Tanulmányok (Gal)

W. LeEDs-Hurwitz: Communication in everyday life: A social interpretation (Fitch)

J. K. LELE \& R. SINGH: Language and society: Steps towards an integrated theory (Apte)

J. M. LIPSKI: The language of the Isleños: Vestigial Spanish in Louisiana (Coles)

P. LOWENBERG (ed.): Language spread and language policy: Issues, implications, and case studies (King)

C. LuCAS (ed.): The sociolinguistics of the Deaf community (Hall) 
J. H. MCDowell: Sayings of the ancestors: The spiritual life of the Sibundoy Indians (Briggs)

D. R. Preston: Perceptual dialectology: Nonlinguists'views of areal linguistics (Butters)

M. Rindal: Ortografi, fonologi og morfologi $i$ Sth. perg. fol. $n r .6$ (Barlaams ok Josaphats saga) (Cathey)

F. Rossi-LANDI: Marxism and ideology (D. Hymes)

A. R. Sarmiento \& A. KaY: Worker-centered learning: A union guide to workplace literacy (K. Hymes)

B. B. SCHIEFFELIN: The give and take of everyday life: Language socialization of Kaluli children (Goldman)

C. Silva-Corvalan: Sociolingüistica: Teoría y análisis (Turell)

G. W. STOCKING, JR.: Victorian anthropology (Leopold)

D. TANNEN: Talking voices: Repetition, dialogue, and imagery in conversational discourse (Folger)

C. TAYLOR: Nkore-Kiga (Wald)

M. Trawick: Notes on love in a Tamil family (Samanta)

S. L. TsohatzIDIs (ed.): Meanings and prototypes: Studies in linguistic categorization (Conklin)

R. vaN Hout \& U. KNops (eds.): Language attitudes in the Dutch language area (Gilbert)

L. S. VIKøR: Språkplanlegging: Prinsipp og praksis (Haugen)

H. WALTER: Le français dans tous les sens (Stevens)

P. E. WeBber: Pella Dutch: The portrait of a language and its use in one of Iowa's ethnic communities (Gilbert)

W. R. WINTEROWD: The culture and politics of literacy (Kimball)

R. WodaK (ed.): Language, power, and ideology: Studies in political discourse (Luong)

K. A. WoOlARD: Double talk: Bilingualism and the politics of ethnicity in Catalonia (Kuter)

K. G. Young: Taleworlds and storyrealms: The phenomenology of narrative (Briggs) 